\title{
The History of Jadid School in Samarkand
}

Jamolova Dilnoza Muyidinovna

Associate Professor, Bukhara State University, Bukhara, Uzbekistan. Email: dilnoza.jamolova@mail.ru

DOI: http://doi.org/10.46382/MJBAS.2021.5202

Copyright: (12021 Jamolova Dilnoza Muyidinovna. This is an open access article distributed under the terms of the Creative Commons Attribution License, which permits unrestricted use, distribution, and reproduction in any medium, provided the original author and source are credited.

ABSTRACT

If we look at history, in the middle of the 19th century in Europe began the modernization of all spheres of society. Asian and African intellectuals as well as enlighteners had also begun practical efforts to bring this innovation to their countries. Reformist movements that emerged in Asian and African countries in the late 19th century soon spread to Central Asia. Reforms in the fields of education, taxation, finance, and state-building united the Turkestan intelligentsia in a common goal, and they began their first steps in reforming the education system. This article describes the Jadid school in Samarkand and its role in the spiritual development of society.

\section{Introduction}

Samarkand Jadidism, which was an integral part of the progressive movement in the history of Turkestan, also began to innovate and change the society and, in a sense, achieved its goals. One of the leading figures of the Samarkand Jadid movement, Abdukadir Shakuri, along with promoting his ideological views on social reform, paid special attention to the issue of the school, which will determine the future of the Turkestan nation. He opened a new methodical school, in which he introduced the teaching of secular sciences.

\section{Discussion}

The role of Samarkand Jadids in the socio-political process of local scholars Dilorom Alimova, Begali Kasimov, Sherali Turdiev, Bahodir Karimov, Ulugbek Dolimov [1]; studied by foreign experts Adam Mets, Mehmet Saray, Ingeborg Baldauf, Ahad Andijan [2], and Abdukadir Shakuri and the school activities he founded have not been studied as a separate study.

At the end of the 19th century, the first attempts to establish Jadid schools began in Samarkand. Ismailbek Gaspirinsky, who visited Bukhara in 1893 at the invitation of Amir Abdullah Khan, also visited Samarkand and met with a group of intellectuals.

Later, the newspaper "Tarjimon" published an article "Machine school" about the details of the trip to Samarkand. The author of the article wrote: "In July 1893 I came to Samarkand on a trip from Bukhara to Turkestan. Abdulgani Boy Husainov (a rich Kazan merchant), who lived in Samarkand that year, heard that I had come and visited the hotel to ask how I was. At the end of our conversation, he invited me to a party tomorrow. I gladly accepted the offer, because at his banquets were gathered the honorable, respectable and, most importantly, intelligent people of Samarkand, whom I needed. If I had a chance, I would be able to tell the public about the method of organizing a savtiya school in Samarkand and its benefits"[3].

The main topic of the reception was the state of Movarounnahr schools, and Abduganiboy asked Ismailbek Gaspirinsky to open a new methodical school in Samarkand. With the support of Samarkand intellectuals, 
Ismailbek will establish a school with 20-30 children. Since teachers from Samarkand do not know the new method, he leaves Sultan Majid Ghanizoda, a Russian language teacher from Baku, who came with him to teach at the school and teach teachers to teach in a new way. During Majid Ghanizada Abdulghani's forty-day teaching career at the school, the children's literacy and mastery of their lessons through exams show parents and school supporters alike. The people of Samarkand call this school, which teaches in a new way, a "machine school".

News of the new methodical school, opened at the initiative of Samarkand intellectuals, will soon reach Tashkent and Fergana, where teaching methods will be reformed. However, thanks to the efforts of the Russian government and fanatical clerics, the Abdulganiboy school will be closed for a year. Years later, Samarkand enlighteners Abdukadir Shakuri, Siddiqi Ajzi, Haji Muin and Mahmudhoja Behbudi opened modern schools.

One of the Jadid schools in Samarkand was a school founded by Siddiqi Ajzi, which operated from 1903 to 1916 in the village of Halvoyi. Siddiqi educated children in a new way, teaching them natural sciences, Arabic/Russian [4].

The school used Ismailbek Gaspirinsky's book "Khojai sibyon" and textbooks for primary school published in Turkey as textbooks. From year to year the number of those who want to study at this school has increased. The Siddiqui Ajzi School still exists today, and in 2018, under the auspices of the Ajzi Generations, the building was renovated and a museum and library were also established.

Another school in Samarkand belonged to Haji Muin and has been operating in Khoja Nisbatdor mahalla since 1903 [5]. Unlike other Jadid schoolchildren, Haji Muin was free to attend his school. He covered her school expenses by buying fruits he grew in her garden in the village of Devoli Transverse. Children aged 8-10 are admitted to the school. Classes began at $8.30 \mathrm{am}$ and ended at 15.00 . There was a big break of 10 minutes and once an hour between classes. At this time, the students prayed the noon prayer with the teachers and were fed with food that everyone brought from home. Haji Muin originally used textbooks published in Turkey and Kazan to teach children. Later he wrote textbooks for primary school and in 1908 published in Persian "Rahnamoi savod", in collaboration with Rahmatullazoda "Alphabet" in Uzbek [6].

The most famous of the new method schools in Samarkand was the Abdukadir Shakuri school. Abdukadir Shakuri was born in 1875 in the village of Rajabamin in Samarkand in a gardener's family. After graduating from the old-fashioned school, he studied at a madrasah in Samarkand. He went to the Russian gymnasium and got acquainted with its internal rules and teaching methods. One of the founders of the Jadid school. In 1921 he was appointed director of the $13^{\text {th }}$ school in Samarkand. For many years he worked as the principal of this school and as a teacher of the native language and literature. In 1925, at the initiative of A. Shakuri, the villagers built a new four-grade school at their own expense. Abdukadir Shakuri died in 1943.

After graduating from the madrasa in 1901, Abdukadir Shakuri began teaching at the old method school. In 1903, in the Beshkuduk mahalla of Kokand, he got acquainted with the school of Salohiddin Majidi, which was opened under the auspices of Umar Haji Munavvar oglu. Upon his return to Samarkand, he opened a Jadid school in the Tajik language, where 25 children could study in his father's garden [7]. He bought new equipment and teaching aids for the school. By 1904, he had built new buildings for the school and divided them into five classes: 
elementary and rushdi (Arabic, "maturity", "perfect"). He was assisted in this work by the enlightened intellectuals of Samarkand Haji Abdukadir, Domullo Mahmud Mudarris, Siddiqi Ajzi. Siddiqi Ajzi taught Uzbek at the Shakuri School for some time. 140-150 students were regularly educated at the school. Semi-annual and annual exams have been introduced at the school. In 1904, Abdukadir Shakuri met Mahmudhoja Behbudi and moved his school to Behbudi's house in the city. Behbudi also provided financial support to the Shakuri school" [8].

Shakuri not only taught, but also wrote textbooks for the school and published them at his own expense. He created textbooks for Shakuri schools, such as Jami ul-Hikayat (1907) and Zubdat ul-Ash'ar (1907). Together with Behbudi, he developed a program for schools. Shakuri also organized a new style school for girls. His wife was a teacher there.

Abdukadir Shakuri traveled to Kazan in 1906, Crimea in 1911, and then to Turkey. The main purpose of these trips was to further improve the activities of Jadid schools, to develop both practical and theoretical bases of teaching methods, to create textbooks, methodological manuals for teachers. In this regard, he visited the famous pedagogue Sote'bek's classes in Istanbul and got acquainted with the alphabet textbook "Khojai avval" (1868) by Ahmad Midhat, which was first created by the Turks in the Savtiya method, he met with Ismailbek Gaspirinsky and brought some copies of his textbook "Khojai sibyon" and the manual "Leader is a teacher or a companion to teachers" [9].

Teacher training courses have also been organized at Shakuri School. They were trained and examined under the guidance of Abduqadir Shakuri. The announcement of the organization of advanced training courses was published in the magazine "Oyina" ("Mirror"): Five teachers are needed to teach Usuli Jadid and primary school in the suburbs of Samarkand. Those who read this ad can come to the "Mirror" office. Those who want to teach will be tested. Those who know how to read, write and be literate will be able to become teachers if their school in Samarkand lasts for a month or two" [10].

Mahmudhoja Behbudi constantly gave methodological advice to Abdukadir Shakuri on school work. In today's parlance, Behbudi was a methodologist at the New Methodist Schools in Samarkand and a supplier of textbooks and manuals. The school used textbooks such as "Risolai asbobi savod" (1905), "Risolai geography umraniy" (1905), "Risolai geography Rusi" (1905), "Kitabat ul-atfol” (1908), "practice Islam" (1908), "History Islam" (1909) [11].

Mahmudhoja Behbudi paid special attention to the development and strengthening of the legal framework of Jadid schools. To this end, Behbudi included the issue of school in paragraphs 17, 18 and 19 of the "Project of Cultural Autonomy of Turkestan", which he submitted in 1907 for consideration in the 3rd State Duma of Russia. Russia's law "On general education" should have the same force for Turkestan, schools and madrassas should be independent of government control, a person in charge of general secondary and higher education should be appointed by Muslims, and Russian should not be introduced in Muslim schools [12].

Behbudi's project was rejected because it ran counter to Russia's colonial interests. By 1909, the opening of Jadid schools in Turkestan was to be strictly controlled by the governor's office. In the same year, a special commission 
under the Turkestan Educational District issued an "Order" on the regulation of schools, which provides for the opening of local schools with the special permission of the Russian administration, that Russian citizens who are politically confident have the right to open local schools, for which nationalities the school is opened for children, the condition that its teachers also belong to that nation, the fact that only books published with the permission of Russian censorship can be taught in local schools, it is the duty of the responsible persons employed in the administrative police offices to ensure accurate registration of all local Muslim schools and prevent the functioning of unregistered schools, those who open a school without a special permit will be permanently deprived of the right to open a school and teach, and strictly established that local administrators and school supervisors are responsible for monitoring the teaching process in schools and compliance with the procedures introduced in them [13].

\section{Results}

The school of Abdukadir Shakuri, which has been suppressed by the Russian government, is also opposed by fanatical scholars. On January 3, 1914, after Friday prayers in the mosque of Ulugbek Madrasah, in front of 5-6 thousand worshipers, Mulla Abbas accused the Jadid schools of infidelity and gave a fatwa: "In Jadid schools, children become irreligious. His teachers and patrons are also atheists and disbelievers. Whoever sends his child to such schools is a disbeliever and his wife is taloq!" [14].

Shakuri school was inspected by N. Ostroumov and Samarkand public school inspector Grachkin and concluded that they should be terminated. The school operated until 1916 with the support of the population. In the same year, in accordance with the decree of the Russian emperor "On the recruitment of non-Russian nationalities of Turkestan”, Samarkand officials were the first to send Abdukadir Shakuri to labor [15].

\section{Conlusion}

In short, the great representative of the Samarkand Jadid movement Abdukadir Shakuri came to the forefront of the struggle for the development of the country and national liberation. He founded a new school of methods, realizing that it was possible to save the nation from decline by educating the people, teaching secular knowledge, and cultivating national cadres.

Despite the colonial policy of the Russian government in the field of education and the opposition of fanatical scholars, he remained steadfast in his ideas. He abandoned the curricula introduced for schools in the $13^{\text {th }}$ century, created new curricula, and wrote textbooks. His school brought with it modernity introduced in Saudi Arabia, Egypt, India and Turkey. In establishing the activities of schools, he established scientific contacts with the Muslim countries of Russia and the progressives of Turkey. As a result, they achieved their goals. So, the talented young people who graduated from his school went abroad, got higher education and became mature professionals.

\section{Declarations}

\section{Source of Funding}

This research did not receive any specific grant from funding agencies in the public, commercial, or not-for-profit sectors. 
Competing Interests Statement

The author declares no competing financial, professional and personal interests.

\section{Ethical Approval}

Ethical approval for this research was given based on institutional guidelines.

\section{Consent to participate}

The consent to participate in this research was sought for and approved by the subjects to be used.

\section{Consent for publication}

Author declares that he/she consented for the publication of this research work.

Availability of data and material

Author is willing to share data and material according to the relevant needs.

\section{References}

1. Alimova D., Rashidova D. Mahmudkhuja Behbudi and his historical views. Tashkent: Manaviyat, 1998; Qosimov B. National Awakening: Courage, Enlightenment, Devotion. Tashkent: Manaviyat, 2002; Dolimov U. Jadid schools in Turkestan. Tashkent: University, 2006.

2. Metz Adam. Muslim Renaissance. Moscow: Science, 1978; Mehmet Saroy. Education Reform in the Turkish World and Gasparali Ismail. Ankara, 1987.

3. Biography of Abdulgani Husaynov and history of Husaynov firm. Orenburg, 1913. p.126.

4. Tursunqul (Rahim Hoshim), Comments on Siddiqui, Education and Teacher, 1928. № 3. p.32.

5. Hoji Muin. Selected works, Completed second edition, Tashkent: "Spirituality", 2010. p.5.

6. Hoji Muin, Selected works, Tashkent: Spirituality, 2010. p.6.

7. Tursunqul, 25-year-old pedagogue, Education and teacher, 1926. № 4. p.29.

8. Tursunqul, 25 years of pedagogue, p.30.

9. Tursunqul, 25 years of pedagogue, p.31.

10. Oyina, 1914. № 13.

11. Dolimov U., Jadid schools in Turkestan, Tashkent: University, 2006. p.102.

12. Behbudiy M., Turkestan Cultural Autonomy Project, World Literature, 2003. № 8., pp.148-157.

13. National Archive of Uzbekistan, fund 47, list 1, collection 929, page 109.

14. Turkestan Regional Newspaper, January 26, 1914, № 8 . 
15. Dolimov U., Jadid schools in Turkestan, p.48.

16. Jamolova D.M., The end of the emirate of Bukhara: the end of the political struggle between the Jadids and the Ulema, International Journal of Philosophical Studies and Social Sciences, 2021, T. 1, №.1.

17. Muyidinovna J.D., "Tarbiyai Atfol" society and its activities, Humanities and Social Sciences in Europe: Achievements and Perspectives, 2016, C. 52.

18. Жамолова Д.М. Жадид матбуотида tуркистон маорифидаги муаммолар тахлили (“Садои фарғона” асосида) //Uzbek Conference Publishing Hub. 2021. T. 1. №. 01. C. 71-74.

19. Muyidinovna J.D. "Tarbiyai Atfol" society and its activities, Humanities and Social Sciences in Europe: Achievements and Perspectives, 2016. C. 52.

20. Жамолова Д.М. Освещение вопросов образования в бухаре на примере произведения «тарихи нофеии», Ученый XXI века, 2016, №. 4-2.

21. Sobirovich T.B. Strategy of Renewal of National Spirituality of Uzbekistan, International Journal on Integrated Education, 2020, T. 3, №. 8, C. 122-126.

22. Sobirovich T.B. Strategy of spiritual renewal in Uzbekistan, International Journal of Psychosocial Rehabilitation, 2020, T. 24, №. 06.

23. Sobirovich T. B. Uzbekistan: from national revival to national progress, Modern scientific challenges and trends, 2020, №. 27, C. 5.

24. Turdiyev Bexruz Sobirovich, Ma'naviy yangilanish: yangi qaror va hayotbaxsh islohotlar strategiyasi, Buxoro davlat universiteti Ilmiy axboroti, 2018.

25. Turdiyev, Bexruz, Behbudi's views on the spiritual renewal of society, Actual problems of social and humanitarian, exact and natural sciences in the modern era., Tadjikistan, Pandjikent, 2021, pp. 550-552.

26. Turdiyev, Bexruz., Ma’naviy yangilanish: yangi qaror va hayotbaxsh islohotlar strategiyasi, Buxoro davlat universiteti Ilmiy axboroti, 2018, 2. 208-2013. 